Saudi Journal of Business and Management Studies Abbreviated Key Title: Saudi J Bus Manag Stud ISSN 2415-6663 (Print) |ISSN 2415-6671 (Online) Scholars Middle East Publishers, Dubai, United Arab Emirates Journal homepage: https://saudijournals.com/sibms

Original Research Article

\title{
Antecedents That Affect Job Satisfaction and Employee Performance Naila Faradila ${ }^{1}$, Ariesta Heksarini ${ }^{2}$, Dio Caisar Darma ${ }^{3 *}$

\author{
${ }^{1}$ Student, Program of Master Management, Faculty of Economics and Business, Mulawarman University, Samarinda, Indonesia \\ ${ }^{2}$ Assistant Professor, Department of Management, Faculty of Economics and Bussiness, Mulawarman University, Samarinda, Indonesia
} \\ ${ }^{3}$ Researcher, Sekolah Tinggi Ilmu Ekonomi Samarinda, Samarinda, Indonesia
}

DOI: $10.36348 /$ sjbms.2020.v05i06.001

| Received: 24.05.2020 | Accepted: 03.06.2020 | Published: 11.06.2020

*Corresponding author: Dio Caisar Darma

\section{Abstract}

In the era of globalization, which is marked by intense competition between hospitals, it requires anticipating improvements in service quality on an ongoing basis in line with the increasingly high expectations of customers for hospital services. This paper presents the quality of internal services and individual characteristics of satisfaction and its implications for employee performance. The population of this study was 56 participants of the Regional General Hospital (Korpri) of East Kalimantan Province through a questionnaire. The analysis model uses Structural Equation Model (SEM) based on Partial Least Square (PLS). Overall, the Quality of Internal Service has a positive and significant effect, while Individual Characteristics have a positive and significant impact on Job Satisfaction. The second model proves that the Quality of Internal Service actually has a positive and significant effect on Employee Performance. On the other hand, Individual Characteristics and Job Satisfaction have a positive impact, but not significant for Employee Performance. In order to improve employee satisfaction and performance through individual characteristics and service quality, there is a need for support from management and fostering good relationships with superiors and colleagues.

Keywords: Quality of internal service, Individual characteristics, Satisfaction, Employee performance, Hospital management.

JEL Codes: L15, R23, J28, J54, M12.

Copyright @ 2020: This is an open-access article distributed under the terms of the Creative Commons Attribution license which permits unrestricted use, distribution, and reproduction in any medium for non-commercial use (NonCommercial, or CC-BY-NC) provided the original author and source are credited.

\section{INTRODUCTION}

Human resource management is a field of management that studies the relationships between people in organizations. In essence, studying the relationship with human resources. The purpose of the organization is to obtain maximum results and also pay attention to performance in the process of these objectives [1].

The competitive climate has also produced positive impacts in the form of advances in health services in Indonesia. This condition has the consequence that hospital managers must be able to face various challenges and provide excellent service for patients. In the era of globalization, which is marked by intense competition between hospitals, it requires anticipating improvements in service quality on an ongoing basis in line with increasingly high customer expectations for hospital services.

So far, the number of hospitals in Indonesia is 1,951 and is growing very rapidly in 2018, which is 2,269 hospitals spread throughout Indonesia Ministry of Health of the Republic of Indonesia, 2018 [2]. Hospitals in East Kalimantan were recorded in 2015 as many as 47 public and private hospitals, then 54 hospitals were divided into 42 general hospitals and 12 special hospitals for 2018 .

Seeing from the available data, the tight competition in the health service industry (hospitals) has led to changes in demand for health services from the community. Patients (customers) who come for treatment at the hospital now expressly state that they not only want to heal but also comfort when treatment. In this connection, the image of the hospital must be 
maintained and built as well as possible and continuously. With a good quality of service, the hospital is expected to attract as many customers as possible, so that it still exists and is competitive.

Employees as important capital or main for the company. In general, three main sources affect the effectiveness of one's performance, namely individual factors, organizational factors, and environmental factors [3]. Employee performance under what was done or not done by the employee [4]. As revealed by Sabil et al., [5], if employees do not get the comfort of work, conflicts will arise when they are unable to balance their duties at work and home.

Employees as human resources must have good quality. The quality of human resources can be demonstrated by the knowledge, skills, and abilities of employees in creating professional quality work in building a teamwork in organizations [6]. The company expects every employee to have a high level of job satisfaction, because with job satisfaction will have a positive impact on the company.

Based on preliminary observations of researchers in the field, as a result of the transfer of authority of the Hospital, which was originally under the Regional General Hospital (RSUD) of AWS Samarinda to move to the East Kalimantan Provincial Health Office, it was identified that there was a decline in performance at the Kopri Samarinda Hospital, such as: timeliness, readiness in completing tasks, and responsibilities. Decreased level of trust and satisfaction with management caused by management policies that are still not taking sides with employees, complaints from employees themselves to colleagues regarding unclear and adequate service standards and procedures, resulting in conflict, dissatisfaction from employees that trigger performance, and lack of communication and collaboration between management and implementing employees. Also, lack of motivation in the context of self-development such as health seminars and training for employees or appreciation of the work done by employees. This is a challenge that must be overcome by the RSUD (Korpri) to create good performance as a result of the transfer of authority, resulting in a repeat of Hospital licensing, Standard Operating Procedures, and policies related to the work environment. Therefore, it can encourage and indirectly see the improvement of maximum employee performance by continuing to make efforts to improve employee performance.

The solution to improve employee performance is through quality of internal service which includes strategic decision making and operational capability through the use of strategic choices. In this case, management is expected to always try to understand and meet needs by fostering a close relationship between fellow employees. The quality of internal services has a direct impact on employee performance. On the other hand, if employees have good performance, this is due to the existence of good quality internal services.

Of the several phenomena that have occurred so far, the quality of internal service can influence employee performance. However, some employee performances are still in the good category even though the quality of internal services is not as expected. This is because of the individual characteristics. Individual characteristics are that each person has different views, goals, needs, and abilities. This difference will carry over into the world of work, which will cause the satisfaction of one person with another different, even though working in the same place. Referring to this description, we feel interested in discussing the quality of internal services and individual characteristics of satisfaction and its implications for employee performance at the Regional General Hospital (Korpri) of East Kalimantan Province.

\section{RELATED LITERATURE}

Evaluation of organizational performance can be done in one way, namely measuring the level of employee satisfaction as feedback and improving the quality of internal services by taking into account the eight components of internal service quality (tools, policies, and procedures, teamwork, management support, alignment of objectives, effective training, communication, appreciation, and recognition). In addition, Hallowel et al., [7] explain that employee job satisfaction has a stronger relationship with internal service quality (non-economic needs) because work will provide more employee satisfaction through developing internal service quality. Memon et al., [8] uncover the reasons and potential results of high levels of stress and low job satisfaction. With a stressful work environment, poor supervisory support, and workload are key factors in influencing stress levels, so job satisfaction decreases.

H1: Quality of internal service affects job satisfaction.

Placement of employees in the field of work per the abilities and skills they have will lead to high job performance and satisfaction [9]. Through experience, a person learns his needs as well as evaluates the organization's remuneration to himself and his involvement in the organization. Through this learning, process experience will influence job satisfaction [10].

H2: Individual characteristics affect job satisfaction.

Several factors contained in the quality of internal services such as the type of management, communication between existing departments, rewards, training, clear job descriptions, and appropriate responsibilities will have a direct impact on performance. For example, Roth \& Jackson [11] in 
empirical research in the financial industry found that the quality of internal services is directly related to company performance [12]. In managing human resources the quality of internal services to employees is a starting point towards superior performance [7].

H3: Quality of Internal service affects performance.

The existence of individual variables such as personality, abilities and skills, perceptions, and attitudes, all of these variables affect the main work behavior such as employee productivity, creativity, and performance. The individual factors or individual characteristics [13]. Heterogeneous individual characteristics of each individual can create different performance contributions to the company. Employees who have good characteristics will make these employees easier to do their jobs so that the resulting performance is optimal and has a very good effect on the company.
H4: Individual characteristics affect employee performance.

It can also be explained that employee job satisfaction will encourage employees to achieve high workability. If applied in an organization, it can be said that organizations with satisfied employees tend to be more effective, so productivity increases [10]. Organizational performance is measured by employee performance, commitment, relationships between employees, and the desire to keep working in the organization. The findings by Morrison \& Robinson [14] indicate that employee job satisfaction has a positive and significant relationship with the four indicators of organizational performance. Among the four indicators of organizational performance, it turns out that job satisfaction has the strongest relationship with employee performance.

H5: Job satisfaction affects employee performance.

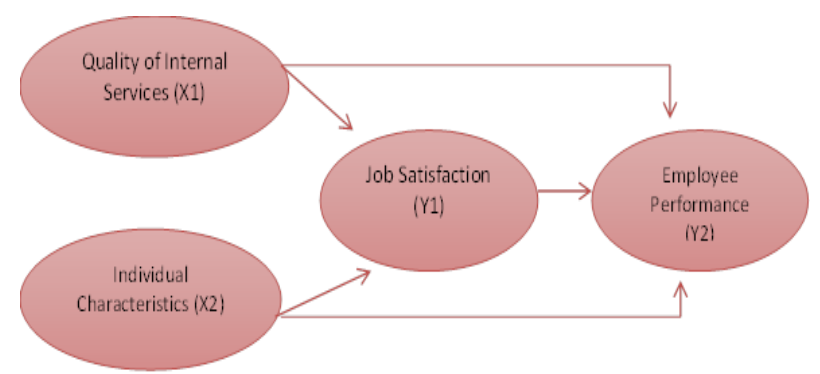

Fig-1: Variable design

In achieving its goals, every organization needs to be encouraged by qualified human resources. To create quality human resources, one of the factors that can influence is employee performance. Employee performance itself can arise through individual characteristics, quality of internal services, and job satisfaction that exists in the work itself. As for the development of hypotheses described earlier, explained through a conceptual framework (see Figure-1).

\section{MATERIAL AND METHODS}

The study site was conducted at the RSUD (Korpri) of East Kalimantan Province, Samarinda City, East Kalimantan Province, Indonesia (75242). The object of this research is a professional clinical staff who directly provide care to patients or Professional Care Providers (PPA), which include doctors, nurses, midwives, dietitians, pharmacists, and others.

The population in this study was PPA with a certain work status totaling 56 participants. In this case, the researcher will take all the population to be used as research samples. Data collection methods used are primary data. Primary data is data obtained from giving questionnaires to research respondents and secondary data, as supplementary data obtained from various information held on the research object, such as data on the number of employees and so on.
Data analysis in the study used Structural Equation Model (SEM), namely Partial Least Square (PLS). In testing the hypothesis, it can be seen from the t-statistic value and the probability value. To test the hypothesis by using a statistical value, then for alpha $5 \%$ the t-statistic value used is 1.96. Criteria for acceptance / rejection of hypotheses, when t-statistics> 1.96. To reject/accept a hypothesis, use probability if the value of $\mathrm{p}<0.05$.

\section{RESULTS}

The characteristics of respondents based on Table 1 are from 56 units, there are 44 female sexes and 12 are male. When looking at the age of the respondents, the dominant is at intervals of 20-30 years (45 people) and the remaining 11 people aged 30-40 years. For respondents with the unmarried status of 30 people, as many as 25 people have been married, and divorced is 1 person. Furthermore, for the most recent education, 38 respondents have completed of diploma, 15 people have completed undergraduate studies, and three high school graduates. After seeing the response during the interview, many employees have worked 3-4 years (29 people), while 18 of them have 1-2 years of working experience, and 2-3 years from 9 employees. 
Table-1: Respective respondents

\begin{tabular}{|l|l|l|}
\hline Description & Category & Total \\
\hline \multirow{3}{*}{ Gender } & Male & 12 \\
\cline { 2 - 3 } & Female & 44 \\
\hline Marital status & 20-30 years old & 45 \\
\cline { 2 - 3 } & 30-40 years old & 11 \\
\cline { 2 - 3 } & Married & 25 \\
\cline { 2 - 3 } & Single & 30 \\
\cline { 2 - 3 } & Divorced / divorcee & 1 \\
\hline Last education & Senior High School & 3 \\
\cline { 2 - 3 } & Diploma & 38 \\
\cline { 2 - 3 } & Bachelor & 15 \\
\hline Length of work & 1-2 years & 18 \\
\cline { 2 - 3 } & 2-3 years & 9 \\
\cline { 2 - 3 } & 3-4 years & 29 \\
\hline
\end{tabular}

Source: Field survey, 2020

Convergent validity of the measurement model with reflexive indicators can be seen from the correlation between item/indicator scores and construct scores. Individual indicators are considered reliable if they have a correlation value above 0.70 . However, at the scale development research stage, loading 0.50 to 0.60 is still acceptable [15]. In this research, a loading factor of 0.60 will be used. The outer loading (convergent validity) results are represented in Table 2 and Figure-2.

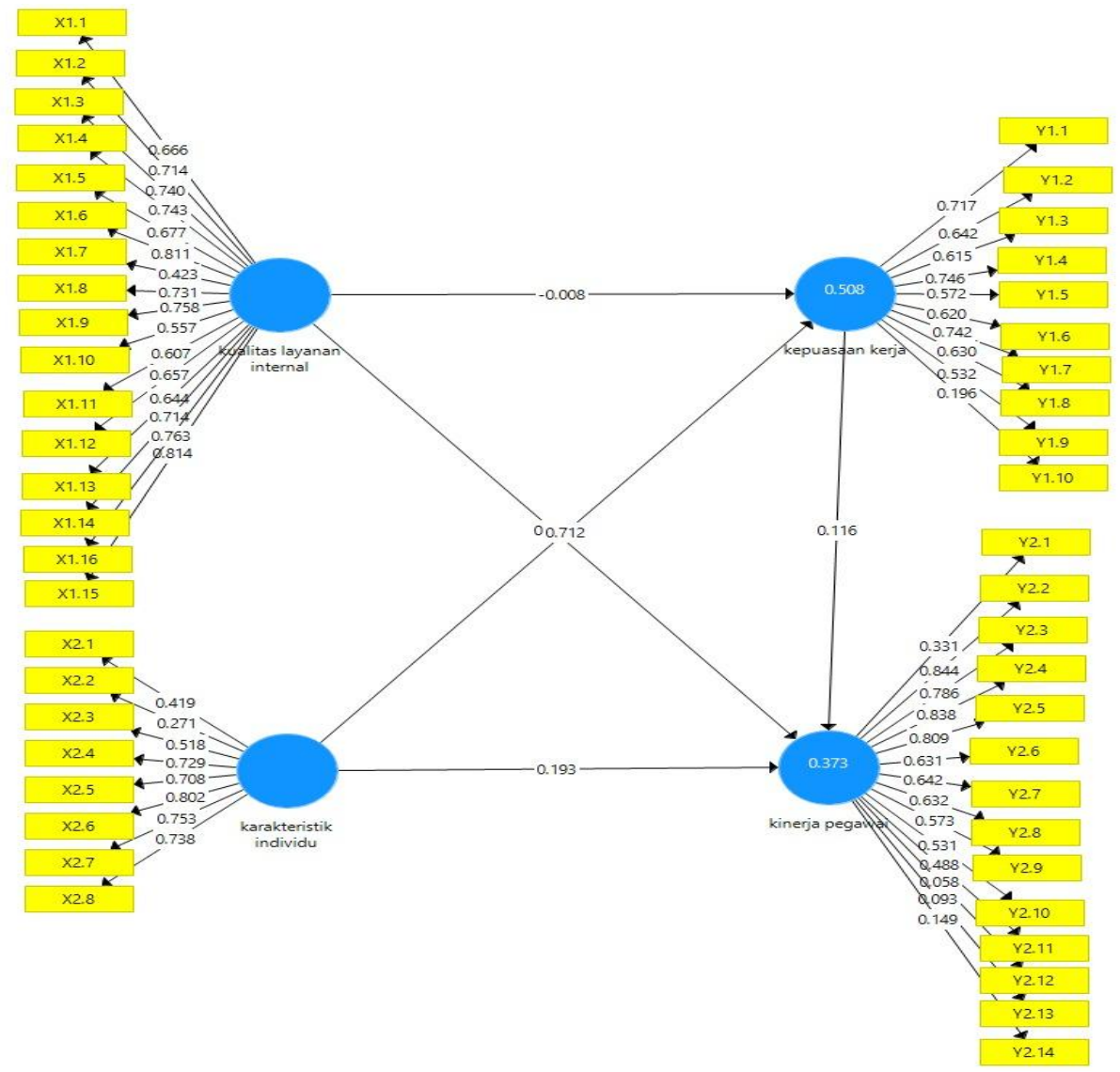

Fig-2: Convergent validity Source: SMARTPLS 3.0 output

In terms of evaluating outer loading, all variable components used have invalid indicators. It can be clarified, that Employee Performance is the most dominant variable and 6 indicators are declared invalid (Y2.9, Y2.10, Y2.11, Y2.12, Y2.13, and Y2.14). while,
Quality of Internal Service is a variable with the least valid indicators (X1.7 and X1.10). For Individual Characteristics and Job Satisfaction variables, both have 3 indicators that are declared invalid (X2.1, X2.2, X2.3, Y1.5, Y1.9, and Y1.10). 
Table-2: Outer loading

\begin{tabular}{|c|c|c|c|c|}
\hline Variables & Indicators & $\begin{array}{l}\text { Outer } \\
\text { Loading }\end{array}$ & Loading Factor & Explanation \\
\hline \multirow[t]{15}{*}{ Quality of Internal Services } & $\mathrm{X} 1.1$ & 0.666 & 0.6 & Valid \\
\hline & $\mathrm{X} 1.2$ & 0.714 & 0.6 & Valid \\
\hline & $\mathrm{X} 1.3$ & 0.740 & 0.6 & Valid \\
\hline & $\mathrm{X} 1.4$ & 0.743 & 0.6 & Valid \\
\hline & $\mathrm{X} 1.5$ & 0.677 & 0.6 & Valid \\
\hline & X1.6 & 0.811 & 0.6 & Valid \\
\hline & $\mathrm{X} 1.7$ & 0.423 & 0.6 & Invalid \\
\hline & $\mathrm{X} 1.8$ & 0.731 & 0.6 & Valid \\
\hline & X1.9 & 0.758 & 0.6 & Valid \\
\hline & $\mathrm{X} 1.10$ & 0.557 & 0.6 & Invalid \\
\hline & $\mathrm{X} 1.11$ & 0.607 & 0.6 & Valid \\
\hline & $\mathrm{X} 1.12$ & 0.657 & 0.6 & Valid \\
\hline & $\mathrm{X} 1.13$ & 0.644 & 0.6 & Valid \\
\hline & $\mathrm{X} 1.14$ & 0.714 & 0.6 & Valid \\
\hline & $\mathrm{X} 1.15$ & 0.814 & 0.6 & Valid \\
\hline \multirow[t]{7}{*}{ Individual Characteristics } & $\mathrm{X} 1.16$ & 0.763 & 0.6 & Valid \\
\hline & $\mathrm{X} 2.1$ & 0.419 & 0.6 & Invalid \\
\hline & $\mathrm{X} 2.2$ & 0.271 & 0.6 & Invalid \\
\hline & $\mathrm{X} 2.3$ & 0.518 & 0.6 & Invalid \\
\hline & X 2.4 & 0.729 & 0.6 & Valid \\
\hline & X2.5 & 0.708 & 0.6 & Valid \\
\hline & X2.6 & 0.802 & 0.6 & Valid \\
\hline \multirow[t]{9}{*}{ Job Satisfaction } & X2.7 & 0.753 & 0.6 & Valid \\
\hline & $\mathrm{X} 2.8$ & 0.738 & 0.6 & Valid \\
\hline & Y1.1 & 0.717 & 0.6 & Valid \\
\hline & $\mathrm{Y} 1.2$ & 0.642 & 0.6 & Valid \\
\hline & Y1.3 & 0.615 & 0.6 & Valid \\
\hline & Y1.4 & 0.746 & 0.6 & Valid \\
\hline & Y1.5 & 0.572 & 0.6 & Invalid \\
\hline & Y1.6 & 0.620 & 0.6 & Valid \\
\hline & Y1.7 & 0.742 & 0.6 & Valid \\
\hline \multirow[t]{17}{*}{ Employee Performance } & Y1.8 & 0.630 & 0.6 & Valid \\
\hline & Y1.9 & 0.532 & 0.6 & Invalid \\
\hline & Y1.10 & 0.196 & 0.6 & Invalid \\
\hline & Y2.1 & 0.331 & 0.6 & Invalid \\
\hline & Y 2.2 & 0.844 & 0.6 & Valid \\
\hline & Y2.3 & 0.786 & 0.6 & Valid \\
\hline & Y 2.4 & 0.838 & 0.6 & Valid \\
\hline & Y2.5 & 0.809 & 0.6 & Valid \\
\hline & Y2.6 & 0.631 & 0.6 & Valid \\
\hline & Y 2.7 & 0.642 & 0.6 & Valid \\
\hline & Y2.8 & 0.632 & 0.6 & Valid \\
\hline & Y2.9 & 0.573 & 0.6 & Invalid \\
\hline & Y2.10 & 0.531 & 0.6 & Invalid \\
\hline & Y2.11 & 0.488 & 0.6 & Invalid \\
\hline & Y2.12 & 0.058 & 0.6 & Invalid \\
\hline & Y 2.13 & 0.093 & 0.6 & Invalid \\
\hline & Y2.14 & 0.149 & 0.6 & Invalid \\
\hline
\end{tabular}

In the next stage, the measurement of discriminant validity is carried out to ensure that each concept of each latent variable is different from the other variables. The model has good discriminant validity if each loading value of each indicator of a latent variable has the greatest loading value with another loading value of another latent variable. The discriminant validity test results are obtained as follows: 
Table-3: Discriminant validity

\begin{tabular}{|c|c|c|c|c|}
\hline Indicators & Quality of Internal Services & Individual Characteristics & Job Satisfaction & Employee Performance \\
\hline $\mathrm{X} 1.1$ & 0.659 & -0.000 & 0.021 & 0.354 \\
\hline $\mathrm{X} 1.2$ & 0.729 & 0.069 & 0.158 & 0.620 \\
\hline $\mathrm{X} 1.3$ & 0.740 & -0.049 & 0.068 & 0.486 \\
\hline $\mathrm{X} 1.4$ & 0.756 & -0.024 & 0.025 & 0.434 \\
\hline $\mathrm{X} 1.5$ & 0.654 & -0.253 & -0.034 & 0.300 \\
\hline $\mathrm{X} 1.6$ & $\mathbf{0 . 8 2 7}$ & -0.138 & -0.095 & 0.404 \\
\hline $\mathrm{X} 1.8$ & 0.704 & -0.016 & -0.036 & 0.255 \\
\hline $\mathrm{X} 1.9$ & 0.750 & -0.070 & -0.104 & 0.375 \\
\hline $\mathrm{X} 1.11$ & 0.600 & -0.217 & -0.051 & 0.155 \\
\hline $\mathrm{X} 1.12$ & 0.646 & -0.233 & -0.026 & 0.206 \\
\hline $\mathrm{X} 1.13$ & 0.643 & -0.149 & -0.009 & 0.299 \\
\hline $\mathrm{X} 1.14$ & 0.709 & -0.031 & 0.010 & 0.358 \\
\hline $\mathrm{X} 1.15$ & 0.836 & -0.032 & 0.077 & 0.560 \\
\hline X1.16 & 0.772 & -0.219 & -0.069 & 0.456 \\
\hline X2.4 & 0.042 & 0.660 & 0.302 & 0.174 \\
\hline $\mathrm{X} 2.5$ & -0.116 & 0.738 & 0.544 & 0.181 \\
\hline X2.6 & -0.073 & 0.847 & 0.630 & 0.076 \\
\hline X2.7 & -0.213 & 0.776 & 0.451 & 0.025 \\
\hline X2.8 & -0.026 & 0.781 & 0.559 & 0.149 \\
\hline Y1.1 & -0.036 & 0.686 & 0.761 & -0.087 \\
\hline Y1.3 & -0.058 & 0.349 & 0.608 & 0.071 \\
\hline Y1.4 & 0.113 & 0.488 & 0.815 & 0.265 \\
\hline Y1.6 & 0.078 & 0.334 & 0.619 & 0.279 \\
\hline Y1.7 & -0.060 & 0.395 & 0.782 & 0.169 \\
\hline Y1.8 & 0.004 & 0.505 & 0.643 & 0.182 \\
\hline Y2.2 & 0.498 & 0.051 & 0.107 & 0.869 \\
\hline Y2.3 & 0.486 & 0.188 & 0.129 & 0.792 \\
\hline Y2.4 & 0.497 & 0.078 & 0.193 & 0.875 \\
\hline Y2.5 & 0.548 & 0.192 & 0.197 & 0.854 \\
\hline Y2.6 & 0.132 & 0.232 & 0.233 & 0.656 \\
\hline Y2.8 & 0.356 & 0.024 & 0.086 & 0.631 \\
\hline
\end{tabular}

Table 3 explains some loading factor values for each indicator of each latent variable which has a loading factor value that is greater than the loading value when connected with other latent variables. This means that each indicator is highly correlated with the indicator compared with other constructs.
Validity and reliability criteria can also be seen from the value of Composite Reliability and the value of Average Variance Extracted (AVE) of each construct. The construct is said to have a high reliability if the value is 0.70 and AVE is above 0.50 [15]. Table 4 presents the Composite Reliability and AVE values for all variables.

Table-4: Composite reliability and AVE

\begin{tabular}{|l|l|l|l|}
\hline Variables & $\begin{array}{l}\text { Composite Reliability } \\
(>\mathbf{0 . 7 0})\end{array}$ & $\begin{array}{l}\text { AVE } \\
(>\mathbf{0 . 5 0})\end{array}$ & Explanation \\
\hline Quality of Internal Services & 0.874 & 0.582 & Reliable \\
\hline Individual Characteristics & 0.857 & 0.504 & Reliable \\
\hline Job Satisfaction & 0.905 & 0.617 & Reliable \\
\hline Employee Performance & 0.937 & 0.517 & Reliable \\
\hline
\end{tabular}

\section{Source: SMARTPLS 3.0 output}

It can be concluded that all constructions meet reliable criteria. This is indicated by the composite reliability value of more than 0.70 and AVE also above the provisions $(0.50$ as a statistical criterion). With additional testing, the inner model or structural model needs to be done by looking at the relationship between constructs, significance values, and R-square. The structural model was evaluated using $\mathrm{R}$-square for the dependent construct of the t-test and the significance of the coefficient of structural path parameters. 


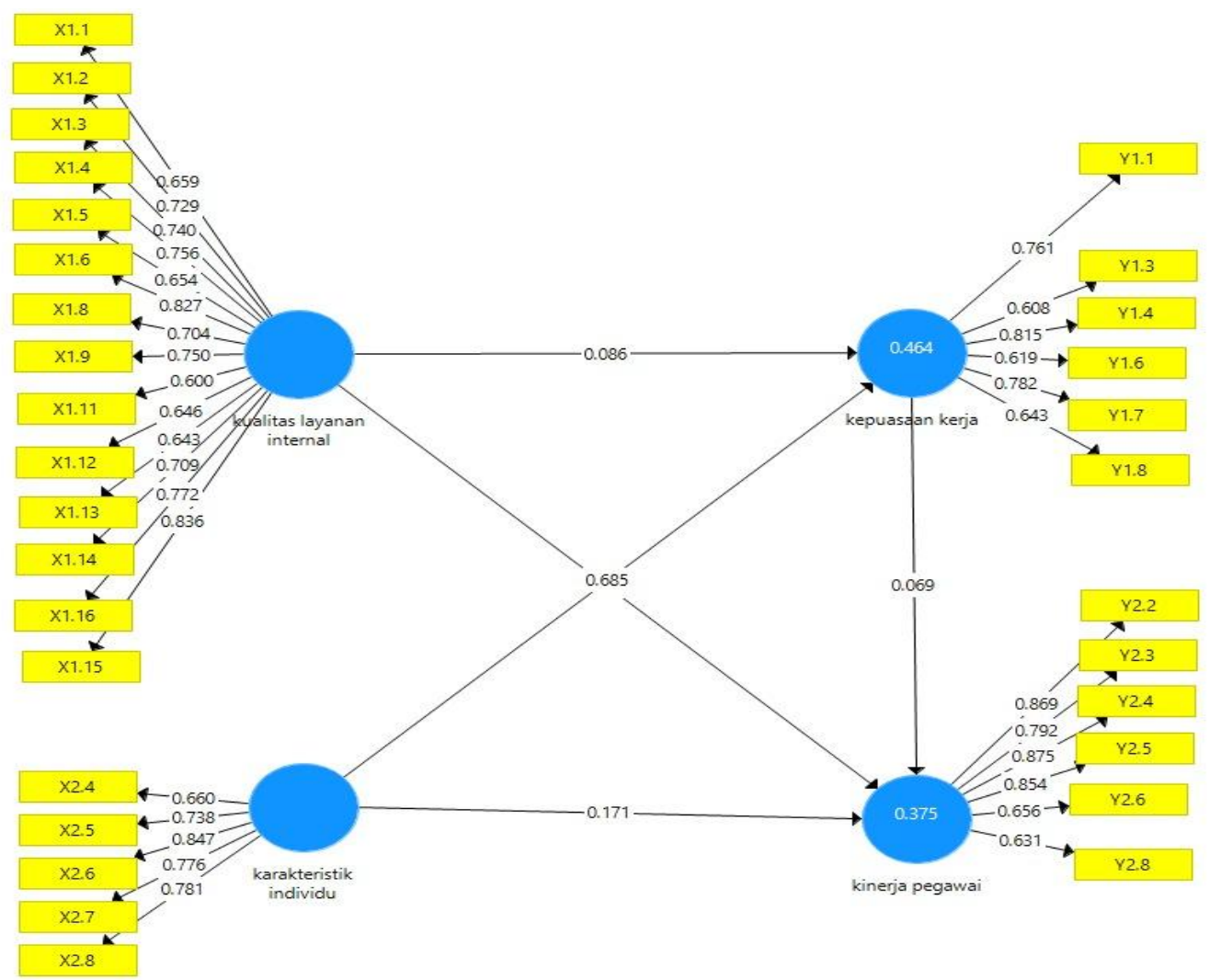

Fig-3: Structural model

Source: SMARTPLS 3.0 output

Testing the inner model or structural model needs to be done to see the relationship between the construct, the significance value, and the R-square of the research model. The structural model is evaluated using R-square for the dependent construct of the t-test as well as the significance of the coefficient of structural path parameters.

In assessing the model with PLS it starts by looking at R-square for the latent dependent variable and Q-square for predictive relevance. Figure-3 shows the R-Square and Q-Square values for job satisfaction and employee performance variables obtained by $\mathrm{R}$
Square of 0.464 and 0.375 while Q Square of 0.444 and 0.339 . These results indicate that endogenous variables get influence from exogenous variables by indicating that the model is moderate and has a predictive value of relevance.

The significance of the modified parameters provides very useful information about the relationship between the research variables. The basis used in testing hypotheses is the value found in the output results for inner weights. Table- 5 provides modification output for structural model testing.

Table-5: Result for inner weight

\begin{tabular}{|l|l|l|l|l|}
\hline & $\begin{array}{l}\text { Original Sample } \\
(\mathbf{O})\end{array}$ & $\begin{array}{l}\text { T- } \\
\text { statistics }\end{array}$ & $\begin{array}{l}\text { T- } \\
\text { table }\end{array}$ & Explanation \\
\hline Quality of Internal Service --> Job Satisfaction & 0.086 & 0.796 & 1.96 & $\begin{array}{l}\text { Positive and not } \\
\text { significant }\end{array}$ \\
\hline Individual Characteristics --> Job Satisfaction & 0.685 & 8.471 & 1.96 & $\begin{array}{l}\text { Positive } \\
\text { and significant }\end{array}$ \\
\hline Quality of Internal Service --> Employee Performance & 0.588 & 7.424 & 1.96 & $\begin{array}{l}\text { Positive } \\
\text { and significant }\end{array}$ \\
\hline Individual Characteristics --> Employee Performance & 0.171 & 1.089 & 1.96 & $\begin{array}{l}\text { Positive and not } \\
\text { significant }\end{array}$ \\
\hline Job Satisfaction --> Employee Performance & 0.069 & 0.408 & 1.96 & $\begin{array}{l}\text { Positive and not } \\
\text { significant }\end{array}$ \\
\hline
\end{tabular}

Source: SMARTPLS 3.0 output 
It can be seen the positive influence and the level of significance of each variable, if the T-statistic> 1.96 means that the exogenous variable has a significant influence on the endogenous variable and if the $\mathrm{T}$ statistic <1.96, the exogenous variable gives no significant effect on the endogenous variable.

\section{DISCUSSION}

First, there is a positive and insignificant influence between the quality of internal services on job satisfaction. In quality of internal service, the most dominant indicators are equipment, policies and procedures, teamwork, training, communication, and appreciation as well as recognition for the dominant indicators, namely management support and work targets that are aligned with the Hospital's vision and mission

The researcher analyzes that the problem currently faced by the Regional General Hospital (Korpri) is the shift of responsibility so that this affects the financial and human resources impacting on the "Type D" Hospital that does not meet the conditions, so this causes a problem that must occur quickly evaluated. If not, then this will significantly affect job satisfaction itself and the impact on services at the Hospital. Especially in quality assurance that must meet the service requirements of the Regional General Hospital (Korpri). This phenomenon is consistent with the results of research Bowen \& Chen [16], that in fact, the quality of internal services will have a positive impact on job satisfaction. With the provision of rewards, training, clear job descriptions, and appropriate responsibilities, resulting in internal quality will affect job satisfaction [17].

Second, there is a positive and significant effect between individual characteristics on job satisfaction in the Regional General Hospital (Korpri) of East Kalimantan Province. The most dominant indicator of the variable of individual characteristics is the attitude and interest in working as well as the value in working which is quite dominant.

Basically, employees have different characteristics or characteristics from the others. Employee differences affect someone in their behavior, not least when they are in the work environment. Different characteristics of employees cause different abilities. Employees in the company have different characteristics from one another when viewed from certain elements. Individuals bring intact characteristics to their workplaces and will influence behavior [18]. Personal characteristics will function as behavioral tendencies that affect certain types of behavior under conditions [19]. Individual characteristics produce different behavior in an effort to meet their needs. Individual characteristics are part of the person and are inherent in a person $[20,21]$.
Third, there is a positive and significant influence between the quality of internal services on the performance of employees of the Regional General Hospital (Korpri) of East Kalimantan Province. The most dominant indicators on the quality of internal services are equipment, policies and procedures, teamwork, training, communication, and appreciation as well as recognition for the dominant indicators, namely management support and work targets that are aligned with the Hospital's vision and mission.

These results support the study of Pillai \& Bagavathi [22] that the success and failure of an organization depend not only on the equipment, machinery, and other materials but precisely on its human resources. Likewise in the service industry, quality human resources (both in terms of nature and knowledge) are needed as implementers, operational support, and management of the service industry [12].

Fourth, there is a positive and insignificant influence between individual characteristics on the performance of employees of the Regional General Hospital (Korpri) of East Kalimantan Province. The individual characteristics have the most dominant indicators, namely attitudes and interests in work as well as work values which are quite dominant. This explains that the employee's characteristics toward performance explain that greater performance is influenced by other factors apart from employee characteristics.

From different studies, Darma et al., [23] presented the indicator values that drive high job characteristics are that employees have the right to make their own decisions in the organization. The value is in the form of job characteristics as the most dominant indicator is employee autonomy and the lowest is the variation in skills. The effect of job characteristics on affective commitment is due to the high level of employee autonomy in the organization because employees are free in making decisions.

Fifth, there is a positive and insignificant influence between job satisfaction on employee performance at the Regional General Hospital (Korpri) of East Kalimantan Province. The job satisfaction variable has several indicators as questions and from the results of its analysis the most dominant indicator is the relationship with superiors and promotions, then for the relatively dominant variable, namely the job itself and coworkers and the most dominant indicator on employee performance compared to others, namely integrity, responsibility, communication, enthusiasm at work, service to consumers, efficiency, and effectiveness.

Referring to this finding, it is considered to have been able to answer the hypothesis about the relationship between job satisfaction and employee 
performance. However, this study did not escape obstacles such as research time which tends to belong because of the licensing process and subjects who are in working hours and assignments out of town when met by researchers. Also, the measuring instrument used to collect data is limited to the scale of job satisfaction and employee performance. This causes researchers to be less able to reveal aspects in depth. The generalization of this study is limited to its population. For this reason, research for more populations requires further research by taking into account other influential factors.

Wijayanti et al., [24] explain the involvement of employees in organizational events is expected not only for the same person but also for alternately. This can be a strategy to foster a sense of belonging to the organization. Indirectly, employees are also committed to improving their performance.

\section{CONCLUSIONS}

Based on the previous discussion, then the things that can be concluded are Quality of Internal Service has a positive and significant effect, while Individual Characteristics have a positive and significant impact on Job Satisfaction. The second model proves that the Quality of Internal Service actually has a positive and significant effect on Employee Performance. On the other hand, Individual Characteristics and Job Satisfaction have a positive impact, but not significant for Employee Performance.

As a way to improve employee performance through quality of internal service which includes strategic decision making and operational capabilities through the use of strategic choices, in this case, management is expected to always try to understand and meet the needs by fostering close relations among fellow employees. The quality of internal services has a direct impact on employee performance. On the other hand, if employees have good performance, this is due to the existence of good quality internal services. Cheng \& Rashid [25] revealed that service quality is vital to the success of any service organization.

It is recommended that researchers who happen to be interested in researching similar cases, should develop problems and develop variables with the support of better and more reliable indicators. Thus, the expected results can reveal more problems and provide research findings that are more meaningful and useful for various groups.

\section{REFERENCES}

1. Purwadi, P., Darma, D. C., Febrianti, W., \& Mirwansyah, D. (2020). Exploration of Leadership, Organizational Culture, Job Satisfaction, and Employee Performance. Technium Social Sciences Journal, 6(1), 116-130.
2. Ministry of Health of the Republic of Indonesia. (2018). Indonesia Health Profile 2017. Jakarta: Ministry of Health Republic of Indonesia.

3. Castetter, W. B. (1981). The Personnel Function in Educational Administration. Pennsylvenia: Macmillan.

4. Mathis, R. L., \& Jackson, J. H. (2008). Human Resource management (12th ed.). South-Western: Thomson.

5. Sabil, F., Abu, H., Kasuma, J., \& Lizzan, N. (2016). Identifying Work-Family Conflict among Nurses: A Qualitative Study. The European Proceedings of Social \& Behavioural Sciences. BE-ci 2016: 3rd International Conference on Business and Economics, 21 - 23 September, 2016.

6. Kreitner, R., \& Kinicki, A. (2007). Organizational Behaviour, Seventh Edition. New York: McGraw Hill International.

7. Hallowell, R. (1996). The Relationship of Customer Satisfaction, Customer Loyalty and Profitability: An Empirical Study. International Journal of Service Industry Management, 7(4), $27-$ 42.

8. Memon, M. A., Ting, H., Salleh, R., \& Kasuma, J., \& Yacob, Y. (2016). Level of Stress and Job Satisfaction among Call Operators: A Case of Malaysian Telecommunication Sector. International Review of Management and Marketing, 6(3), 442-447.

9. George, J. M., \& Jones, G. R. (2002). Organizational Behaviour. New Jersey: Prentice Hall.

10. Robbins, S. P., \& Sanghi, S. (2006). Organizational Behavior (11th Ed.). Delhi: Dorling Kindersley (India) Pvt.

11. Roth, A. V., \& Jackson, W. E. (1995). Strategic Determinants of Service Quality and Performance: Evidence from the Banking Industry. Managemenet Science, 41(11), 1720-1733.

12. Siehoyono, L. (2006). Analisa Hubungan Latar Belakang Karyawan dan Pengaruh Kualitas Layanan Internal Terhadap Kepuasan Karyawan di Hotel X Surabaya. Jurnal Manajemen Perhotelan, 2(1), 18-26.

13. Ivancevich, J. M. (2007). Human Resource Management. New York: McGraw Hill International.

14. Morrison, E. W., \& Robinson, S. L. (1997). When employees feel betrayed: A model of how psychological contract violation develops. The Academy of Management Review, 22(1), 226-256.

15. Ghozali, I., \& Latan, H. (2015). Partial Least Squares: Konsep, Teknik dan Aplikasi Menggunakan Program Smart PLS 3.0 (Edisi kedua). Semarang: Universitas Diponegoro.

16. Bowen, J. T., \& Chen, S. (2001). The relationship between customer loyalty and customer satisfaction. International Journal of 
Contemporary Hospitality Management, 13(4/5), 213-217.

17. Jeng, D. J., \& Kuo, S. F. (2012). Internal service quality within the different Chinese subcultures: a comparison between Taiwan, China, and Singapore. Serv Bus 6, 425-458.

18. Robbins, S. P., \& Judge, T. A. (2008). Essential organisational behaviour. Upper Saddle River, NJ: Pearson Education Inc.

19. Bangun, W. (2012). Manajemen Sumber Daya Manusia. Bandung: Erlangga.

20. Damihartini, R. S., \& Jahi, A. (2005). Hubungan Karakteristik Petani dengan Kompetensi Agribisnis pada Usahatani Sayuran di Kabupaten Kediri Jawa Timur. Jurnal Penyuluhan, 1(1), 4248.

21. Rogers, E. M., \& Shoemaker, F. F. (1971). Communication of Innovations. New York: The Free Press.
22. Pillai, R. S. N., \& Bagavathi, B. (2003). Office management. New Delhi: Chand \& Company Ltd.

23. Darma, D. C., Purwadi, P., Sundari, I., Hakim, Y.P., \& Pusriadi, T. (2020). Job Characteristics, Individual Characteristics, Affective Commitments and Employee Performance. Research and Review: Human Resource and Labour Management, 1(1), 7-18.

24. Wijayanti, T. C., Setini, M., Darma, D. C., Purwadi, P., \& Alka, P. R. (2020). Connectivity Continuous Improvement Program and Employee Performance. International Review of Management and Marketing, 10(1), 54-62.

25. Cheng, B., \& Rashid, M.Z. (2013). Service Quality and the Mediating Effect of Corporate Image on the Relationship between Customer Satisfaction and Customer Loyalty in the Malaysian Hotel Industry. Gadjah Mada International Journal of Business, 15(2), 99-112. 